\title{
Efficacy of the entomopathogenic nematode, Steinernema feltiae (Filipjev) (Rhabditida: Steinernematidae) on Mecorhis ungarica (Herbst, 1784) (Coleoptera: Rhynchitidae)
}

\author{
Asiye Uzun *i), Fatma Gül Göze Özdemir(i) and Ozan Demirözer®D
}

\begin{abstract}
Background: In this study, the virulances of 4 different concentrations of the entomopathogenic nematode, Steinernema feltiae (Filipjev) on adults of the rose weevil, Mecorhis ungarica (Herbst, 1784) (Coleoptera: Rhynchitidae) were tested under laboratory conditions.

Results: Ten replications for each concentration where 5 adults for each replicate were used. Suspensions prepared from each concentration, containing 3 rd instar juveniles (infective juveniles) of S. feltiae, were sprayed on the pest adults for $20 \mathrm{~s}$ at $1 \mathrm{~atm}$ pressure. Deltamethrin was applied, at the recommended concentration (30 ml/ha), as a positive control, while pure water was used as negative control. Observations started $72 \mathrm{~h}$ after the applications and continued until the 15th day. The White Trap Method used for the reisolation of nematodes from dead individuals obtained in observation days. As a result of the study, obtained mortality rates in concentration of S. feltiae $(100,150,200,250$ million IJS/100 I water) were not different from each other but were found significant than control $(P<0.05)$. Additionally, among the number of re-isolated 3rd juveniles, the highest mean number was found on 200 million IJs concentration and the lowest mean was determined on 150 million IJs concentration. Tested concentrations of S. feltiae caused 80, 86, 82, and $92 \%$ death on adult individuals on the 15th day. Mortality rates caused by each concentration depending on the time were not significant between each other $(P>0.05)$.

Conclusion: In this study, it was determined that different concentrations of $S$. feltiae were effective on adults of rose weevil. It is thought that entomopathogenic nematodes may be an alternative and promising biological control strategy to reduce the risk of pesticide residues in oil-bearing rose production areas.
\end{abstract}

Keywords: Rose weevil, Mecorhis ungarica, Entomopathogenic nematodes, Steinernema feltiae, Virulance

\footnotetext{
* Correspondence: asiyeuzun@isparta.edu.tr

Department of Plant Protection, Faculty of Agriculture, Isparta University of Applied Sciences, 32200 Isparta, Turkey
}

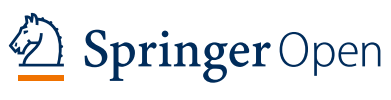

(c) The Author(s). 2021 Open Access This article is licensed under a Creative Commons Attribution 4.0 International License which permits use, sharing, adaptation, distribution and reproduction in any medium or format, as long as you give appropriate credit to the original author(s) and the source, provide a link to the Creative Commons licence, and indicate if changes were made. The images or other third party material in this article are included in the article's Creative Commons licence, unless indicated otherwise in a credit line to the material. If material is not included in the article's Creative Commons licence and your intended use is not permitted by statutory regulation or exceeds the permitted use, you will need to obtain permission directly from the copyright holder. To view a copy of this licence, visit http://creativecommons.org/licenses/by/4.0/. 


\section{Background}

The rose weevil, Mecorhis ungarica (Herbst, 1784) (Coleoptera: Rhynchitidae) is one of the important pests that caused damage to Rosaceae. Adult females break the rosebuds and hatched larvae feed inside the buds, so the buds do not open, produce abnormal flowers, and yield decreases. As in all conventional farming systems, the first tendency of farmers for the management of a pest such as rose weevil, unfortunately, is the use of chemical pesticides. This control strategy has led to pesticide residues in all oil-rose products that created problems in the export of the products (Kumar et al. 2004). Thus, biological control methods can be hopeful, safer, and sustainable for pest control in oil-bearing rose cultivation. The entomopathogenic nematodes (EPN); Heterorhabditis and Steinernema species are among the most known and important biological control agent that their uses have been increased in recent years (Susurluk and Ökten 2000). EPN species are symbiotically associated with Xenorhabdus spp. and Photorhabdus spp., which are harbored in the intestine of the third-stage infective dauer juvenile (DJ) (Ciche et al. 2006). They enter the insects' hemolymph through natural openings and release their bacteria inside the hosts to die because of septicemia within 24 to $48 \mathrm{~h}$ (Stock and Goodrich-Blair 2008). In this way, these symbiont bacteria are responsible for causing death of the host (Susurluk 2008).

The present study aimed to evaluate the efficacy of the EPN, Steinernema feltiae on adults of $M$. ungarica under laboratory conditions.

\section{Main text}

Four different concentrations of the entomopathogenic nematode S. feltiae (Bioglobal Co.; 100 (recommended concentration), 150, 200, and 250 million infective juveniles (IJs)/100 l water), and field concentration of deltamethrin (pyrethroid 3A) (Delmetrin, Tarkim Plant Protection Industry and Trade Inc., Turkey) were tested under laboratory conditions. Adult individuals of $M$. ungarica were obtained from an organic rose production area in district of Isparta in Turkey.

\section{Method}

The effects of 4 different concentrations of S. feltiae on adult individuals of $M$. ungarica were tested under laboratory conditions $\left(25-30{ }^{\circ} \mathrm{C}, 30-40 \%\right.$ humidity). In the trial, 10 replicates per concentration (5 adults per replicate) were used. Suspensions prepared for each concentration, containing 3rd instar juveniles (IJs) were sprayed at $1 \mathrm{~atm}$ pressure for $20 \mathrm{~s}(0.3 \mathrm{ml}$ suspension for each Petri dish including 5 adult individuals) after then adults were placed into boxes $(8 \times 12.5 \times 9 \mathrm{~cm})$. Fresh rose flowers were brought from the organic rose production area for feeding of adult individuals and were renewed periodically in the boxes. Deltamethrin was applied at the recommended dose $(30 \mathrm{ml} / \mathrm{ha})$, as positive control and pure water was used as negative control. Observations of $M$. ungarica started $72 \mathrm{~h}$ after the applications of suspensions and continued until the 15th day. The White Trap Method (Kaya and Stock 1997) was used for the re-isolation of nematodes from dead individuals obtained throughout the observation days. On each observation day, dead individuals were taken from the boxes, transferred to White traps and incubated in distilled water at the dark at $20{ }^{\circ} \mathrm{C}$ for 15 days. After incubation, nematode suspensions were placed in measuring cylinders and $8 \mathrm{~h}$ was waited for precipitation, the supernatant discarded, and the concentrated nematodes were transferred into $15-\mathrm{ml}$ tubes. Nematodes were counted under the light microscope at $\times 100$ magnification (Olympos BX51).

\section{Statistical analysis}

One-way Anova test was applied to the parametric mortality values of $M$. ungarica and the number of the reisolated nematodes that 3rd juvenile stage, followed by Tukey's HSD (honestly significant difference) test was performed $(P<0.05)$. The statistical software package SPSS 20.0 was used for all statistical analyses.

\section{Results}

The present study is the first experiment of EPNs on $M$. ungarica. According to the concentration and the mortality interaction, the mortality rates (\%) were not different among the concentrations S. feltiae (100, 150, 200, 250 million IJs/100 l water), whereas these rates were significant than control. The mortality rate in case of the deltamethrin, the chemical originated insecticide studied as a positive control, was non-significant compared to all other applications.

Even though non-significant difference was found among mortality rates caused by the concentrations applied on rose weevil. There were little differences in mortality rates caused by 100, 150, and 200 million IJs/ 1001 water concentrations of S. feltiae depending on time. However, the 100 million IJs/100 l water concentrations of $S$. feltiae showed that mortality rates in the other observation days (6th, 9th, 12th, and 15th) were more significant than the 3th day $(P<0.05)$. While the 150 million IJs/100 I water concentrations of $S$. feltiae reached the highest mortality rate on the 12th day, at the 200 million concentrations occurred the highest mortality rate on the 9th day. It was determined that for only 250 million IJs/100 l water concentrations of $S$. feltiae was no difference among time-dependent mortality rates (3th, 6th, 9th, 12th, and 15th). In all observation times, no differences were found between mortality rates that occurred at the 100, 150, 200, and 250 million IJs/ 
Table 1 Time-dependent mortality rates (\%) of different concentrations of Steinernema feltiae on Mecorhis ungarica

\begin{tabular}{|c|c|c|c|c|c|c|}
\hline \multirow[t]{2}{*}{ Time (day) } & \multicolumn{6}{|c|}{ Treatments and mortality rates (\%) } \\
\hline & $100 \mathrm{M} \mathrm{IJs} / 100 \mathrm{I} \mathrm{W}$ & $150 \mathrm{M}$ IJs/100 I W & 200 M IJs/100 I W & $250 \mathrm{M}$ IJs/100 I W & Control & Deltamethrin \\
\hline $3^{\text {th }}$ & $50 \mathrm{aB}$ & $46 \mathrm{aB}$ & $46 \mathrm{aB}$ & $74 \mathrm{aA}$ & 0 bA & $100 \mathrm{cA}$ \\
\hline $6^{\text {th }}$ & $72 \mathrm{aA}$ & $64 \mathrm{aAB}$ & $70 \mathrm{aAB}$ & $84 \mathrm{aA}$ & 0 bA & $100 \mathrm{cA}$ \\
\hline $9^{\text {th }}$ & 76 aA & $70 \mathrm{aAB}$ & 78 aA & 88 aA & 0 bA & $100 \mathrm{cA}$ \\
\hline $12^{\text {th }}$ & 76 aA & $80 \mathrm{aA}$ & $80 \mathrm{aA}$ & $88 \mathrm{aA}$ & 0 bA & $100 \mathrm{cA}$ \\
\hline $15^{\text {th }}$ & $80 \mathrm{aA}$ & 86 aA & $82 \mathrm{aA}$ & $92 \mathrm{aA}$ & 0 bA & $100 \mathrm{cA}$ \\
\hline
\end{tabular}

" $\mathrm{A}$ " and " $\mathrm{B}$ " mean followed by different letter in the same column are different $(P<0.05)$; "a", " $\mathrm{b}$ ", and " $\mathrm{C}$ " mean followed by different letter in the same row is not different $(P<0.05)$

1001 water concentrations of $S$. feltiae $(P>0.05)$ (Table 1).

The mean number of re-isolated 3rd juvenile stage of nematodes per individual from $M$. ungarica adults treated with 4 different concentrations of S. feltiae is given in Fig. 1. The highest mean number of 3rd juvenile was found 200 million IJs/100 l water concentration of $S$. feltiae and the lowest mean number was also 150 million IJs/100 l water concentration. No difference found between other concentrations for mean number of reisolated 3rd juvenile stage from adult of $M$. ungarica. Re-isolation data of the 3rd juvenile stage of entomopathogenic nematodes after reproducing in the host are of great importance in terms of maintaining the population of EPNs in the environment and thus the sustainability of the pest control.

\section{Discussion}

Entomopathogenic nematodes (EPNs) attacks usually cause death of their hosts. Studies associated with the use of EPNs against the coleopteran species under laboratory and field conditions were conducted. Laznik and Trdan (2015) determined that the most effective combination was EPFs (B. brongniartii, B. bassiana) and $H$. bacteriophora to control first and second instar larvae of the white grubs (Coleoptera: Scarabaeidae). EPNs have many superior features such as easy commercial productions in vivo or in vitro, long-term effect, easy application, application with many chemicals safety for the environment and human health, pathogenicity, host search behavior, and survivability (Canhilal 2011). Pathogenicity, invasion and reproductive capacity of EPNs are important in terms of persistence and settlement in areas where they are applied (Susurluk and Ehlers 2008; Susurluk et al. 2009). It is known that the effectiveness of EPNs species can vary according to abiotic factors such as air and soil temperature under natural conditions. However, the EPN formulations lose their moisture within a few days and cannot support enough humid condition that needs for EPN survival (Lacey and

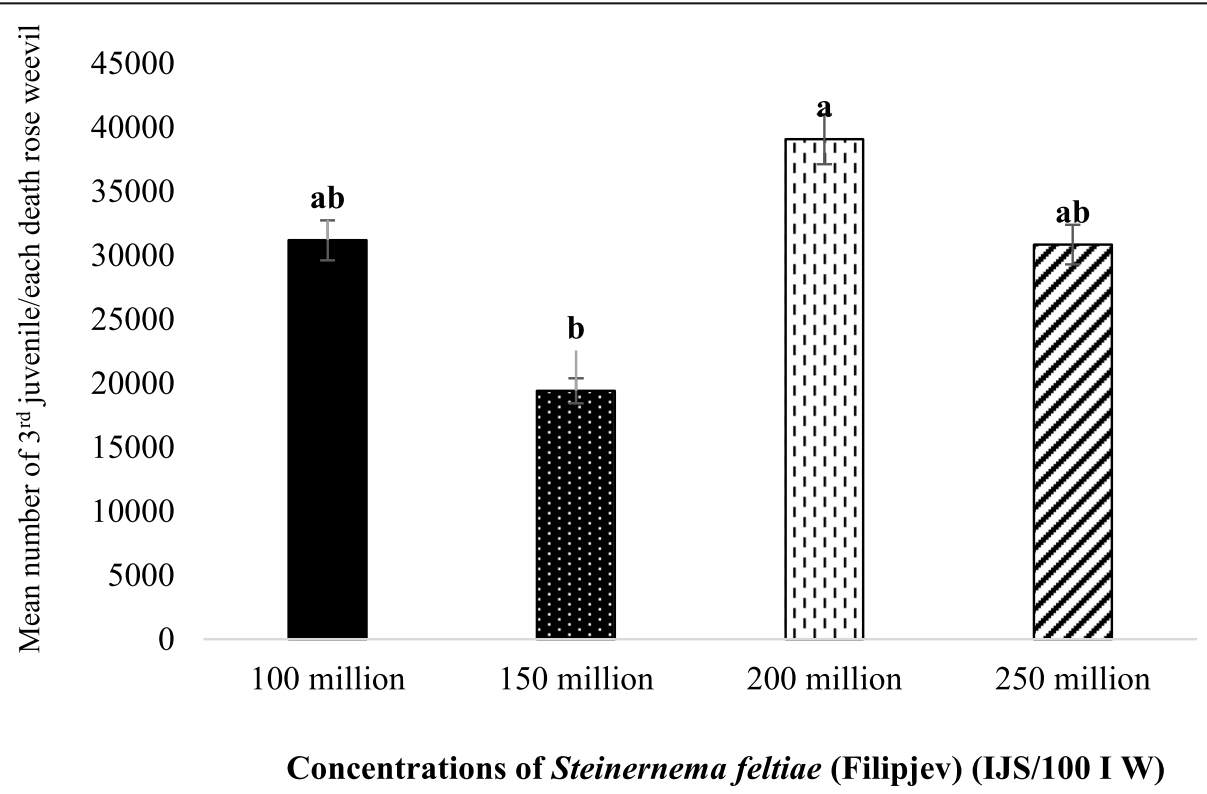

Fig. 1 Mean number of re-isolated 3rd juveniles from Mecorhis ungarica at different concentrations of Steinernema feltiae 
Georgis 2012). Susurluk (2008) reported that S. feltiae and S. weiseri might be more effective against Bothynoderes punctiventris Germar another species of Curculionidae, early in the growing season when the soil temperature is low. However, H. bacteriophora might be more effective later in the season when the temperature increases, in the same study. Manzoor et al. (2017) reported that adult stage of mortality rate of Rhynchophorus ferrugineus (Coleoptera: Curculionidae) due to inoculation of S. carpocapsae, $H$. bacteriophora, and $S$. feltiae were $3.07,0.66$, and $0 \%$, respectively. In the present study, 4 different concentrations of S. feltiae caused $80-92 \%$ mortality on adults $M$. ungarica 15 th day after application. According to the obtained results, the time elapsed after application of the EPN, S. feltiae to adults of rose weevil had an effect on mean mortality rates under laboratory conditions. In addition that EPNs sensitivity to temperature and moisture in fields limit, its persistence at high densities and dramatic seasonal fluctuations and a lack of spatial association with hosts decrease the predictability of the nematodes' impact on $M$. ungarica. Therefore, more research is needed under field conditions to increase the chances of success of using EPNs in biological control programs.

\section{Conclusion}

It was concluded that $S$. feltiae can obviously be effective in control of the rose weevil. However, it was believed that this information based on the results obtained under laboratory conditions should be tested primarily in open field conditions.

\section{Abbreviations}

EPN: Entomopathogenic nematodes; N: Number of individuals; S. feltiae: Steinernema feltiae; M. ungarica: Mecorhis ungarica; IJs: Infective juveniles; DJ: Dauer juvenile; M: Million; W: Water; Anova: Analysis of variance; HSD: Honestly significant difference; Inc.: Incorporation

\section{Acknowledgements}

We would like to thank Bioglobal Company, Antalya, Turkey, for providing the entomopathogenic nematode preparation.

\section{Authors' contributions}

Study conception and experimental design were performed by OD, AU, and FGGÖ. Data collection was performed by AU and FGGÖ. Data analysis was performed by OD. The manuscript was written by OD, AU, and FGGÖ. The authors read and approved the final manuscript.

\section{Funding}

Not applicable.

\section{Availability of data and materials}

All data generated or analyzed during this study are included in this article. The authors also declare that they have no conflict of interest.
Consent for publication

Not applicable.

\section{Competing interests}

The authors declare that they have no competing interests.

Received: 19 January 2021 Accepted: 26 April 2021

Published online: 12 May 2021

\section{References}

Canhilal R (2011) Heterorhabdit Nematodların (Rhabditida: Heterorhabditidae) Biyolojik Etkinliklerinin Galleria mellonella L. (Lepidoptera: Pyralidae) Üzerinde Karşılaştırılması. GOÜ Ziraat Fakültesi Dergisi 28(2):43-52

Ciche TA, Darby C, Ehlers RU, Forst S, Goodrich-Blair H (2006) Dangerous liaisons: the symbiosis of entomopathogenic nematodes and bacteria. Biological Control 38(1):22-46. https://doi.org/10.1016/j.biocontrol.2005.11.016

Kaya HK, Stock S (1997) Techniques in insect nematology. Man Tech Insect Pathol 1:281-324

Kumar A, Nadda G, Shanker A (2004) Determination of chlorpyrifos 20\% EC (Dursban $20 \mathrm{EC}$ ) in scented rose and its products. J Chromatogr A 1050(2): 193-199. https://doi.org/10.1016/S0021-9673(04)01400-1

Lacey LA, Georgis R (2012) Entomopathogenic nematodes for control of insect pests above and below ground with comments on commercial production. J Nematol 44(2):218-225

Laznik Ž, Trdan S (2015) Failure of entomopathogens to control white grubs (Coleoptera: Scarabaeidae). Acta Agric Scand Section B-Soil Plant Sci 65(2): 95-108. https://doi.org/10.1080/09064710.2014.968199

Manzoor M, Ahmad JN, Sharif MZ, Majeed D, Kiran H, Jafir M, Ali H (2017) Comparative effectiveness of entomopathogenic nematodes against red palm weevil (Rhynchophorus ferrugineus) in Pakistan. J Entomol Zool Stud 5: 756-760

Stock SP, Goodrich-Blair H (2008) Entomopathogenic nematodes and their bacterial symbionts: the inside out of a mutualistic association. Symbiosis 46 : $65-75$

Susurluk A (2008) Potential of the entomopathogenic nematodes Steinernema feltiae, S. weiseri and Heterorhabditis bacteriophora for the biological control of the sugar beet weevil Bothynoderes punctiventris (Coleoptera: Curculionidae). J Pest Sci 81(4):221-225. https://doi.org/10.1007/s10340-0080209-x

Susurluk A, Ehlers R-U (2008) Field persistence of the entomopathogenic nematode Heterorhabditis bacteriophora in different crops. Biocontrol 53: 627-641

Susurluk IA, Kumral NA, Peters A, Bilgili U, Açıkgöz E (2009) Pathogenicity, reproduction and foraging behaviours of some entomopathogenic nematodes on a new turf pest, Dorcadion pseudopreissi (Coleoptera: Cerambycidae). Biocontrol Sci Technol 19(6):585-594. https://doi.org/10.1080/ 09583150902957348

Susurluk IA, Ökten ME (2000) Bazı Entomopatojen Nematodların Blattella germanica L. (Dictyoptera: Blattellidae) Üzerindeki Etkileri. Tarım Bilimleri Dergisi 6(4):111-114. https://doi.org/10.1501/Tarimbil_0000001005

\section{Publisher's Note}

Springer Nature remains neutral with regard to jurisdictional claims in published maps and institutional affiliations.

\section{Declarations}

